\title{
Ultrastructure of surface components of Streptococcus gallolyticus (S. bovis) strains of differing virulence isolated from pigeons
}

\author{
Mia Vanrobaeys, ${ }^{1}$ Peter De Herdt, ${ }^{1}$ Gerard Charlier, ${ }^{2}$ Richard Ducatelle ${ }^{1}$ \\ and Freddy Haesebrouck ${ }^{1}$
}

Author for correspondence: Mia Vanrobaeys. Tel: +329264 74 31. Fax: + 3292647494 .

e-mail: Mia.Vanrobaeys@rug.ac.be

1 Department of Pathology, Bacteriology and Avian Diseases and Laboratory of Veterinary Bacteriology and Mycology, Faculty of Veterinary Medicine, University of Ghent, Salisburylaan 133, 9820 Merelbeke, Belgium

2 Laboratory of Electron Microscopy, Veterinary and Agrochemical Research Centre (VAR), Groeselenberg 99, 1180 Brussels, Belgium

\begin{abstract}
Virulence of Streptococcus gallolyticus (S. bovis) strains isolated from pigeons is associated with the presence of the extracellular proteins A, T1, T2 and T3. Based on the presence or absence of these proteins, six supernatantphenotypes are distinguished. Experimental infection studies have indicated that strains belonging to the $A^{-} T 1, A^{+} T 1, A^{+} T 2$ and $A^{+} T 3$ groups are highly virulent for pigeons, strains belonging to the $A^{-} T 3$ groups are moderately virulent and $A^{-}-12$ strains are of low virulence. In this study the surface structure of 15 pigeon S. gallolyticus strains representing high, moderate and low virulence supernatant-phenotypes was examined by electron microscopy. The presence of capsular material was determined by transmission electron microscopy after polycationic ferritin labelling and immunostabilization. Capsules from cells labelled with polycationic ferritin were usually thicker than those from cells exposed to antiserum. The capsule of the virulent strains had a regular, continuous appearance whilst irregularity of the capsule was a characteristic of the low virulence $A^{-}-12$ strains. Negative staining revealed the presence of fimbriae in all strains belonging to the high virulence $A^{-} T_{1}, A^{+} T_{1}$, $A^{+} T 2$ and $A^{+} T 3$ supernatant groups and in one strain of the moderately virulent A-T3 group. The fimbriae were thin, flexible structures with a diameter of approximately 3-4 nm and a length of up to $700 \mathrm{~nm}$. Fimbriae as described above were absent in two other $A^{-}-13$ strains examined and in the low virulence $A-T 2$ strains. Results from this study indicate that morphological differences in surface structure exist among virulent and low virulence pigeon S. gallolyticus strains, and that the capsule and/or fimbriae are possibly involved in virulence.
\end{abstract}

Keywords: Streptococcus gallolyticus (S. bovis), capsule, fimbriae, virulence, pigeon

\section{INTRODUCTION}

Streptococcosis is an important septicaemic disease in pigeons (De Herdt et al., 1991, 1994a; Devriese et al., 1990). The most important clinical signs of Streptococcus gallolyticus septicaemia include sudden death, inability to fly, lameness, emaciation, polyuria and production of slimy, green droppings (De Herdt et al., 1994b; Devriese et al., 1990). Most typical lesions consist of extensive, well-circumscribed areas of necrosis in the pectoral muscle, and arthritis of the knee, hock and shoulder joints (De Herdt et al., 1992b, 1994c).

The aetiological agent of streptococcosis in pigeons is
Streptococcus gallolyticus, which was formerly identified as S. bovis (Devriese et al., 1998). Within this species, different types have been recognized in pigeons: five biotypes, two sub-biotypes, five serotypes and six supernatant-phenotypes (De Herdt et al., 1992a; Vanrobaeys et al., 1996). Biotypes and sub-biotypes are determined by a series of biochemical properties whilst serotypes are distinguished by agglutination (De Herdt et al., 1992a). Biotypes 1 and 2 are the most common biotypes of pigeon $S$. gallolyticus strains, representing $96 \%$ of our collection. Serotype 4 strains are extremely rare in pigeons and may be an accidental finding. Supernatant-phenotypes are identified on the basis of the presence of either a T1, T2 or T3 protein triplet and 
the presence or absence of a $185 \mathrm{kDa}$ A protein in $S$. gallolyticus culture supernatant (Vanrobaeys et al., 1996). Classification of strains according to serotype or biotype is not very well correlated with virulence, whereas there is a very strong correlation between the supernatant-phenotype and the virulence of a given strain. Indeed, experimental infection studies have demonstrated that the $\mathrm{A}^{+} \mathrm{T} 1, \mathrm{~A}^{+} \mathrm{T} 2, \mathrm{~A}^{+} \mathrm{T} 3$ and $\mathrm{A}^{-} \mathrm{T} 1$ phenotype groups are highly virulent for pigeons, with a postinoculation morbidity of $70-100 \%$. $\mathrm{A}^{-} \mathrm{T} 3$ strains appear moderately virulent and strains belonging to the $\mathrm{A}^{-} \mathrm{T} 2$ are of low virulence for pigeons. The morbidity in these groups following experimental infections was $37 \%$ and $5 \%$, respectively (Vanrobaeys et al., 1997). Any type of S. gallolyticus can be part of the normal intestinal flora in pigeons. S. gallolyticus is therefore considered to be a facultative pathogenic agent.

Virulence factors of $S$. gallolyticus are still insufficiently understood. The present article aims to contribute to the knowledge of $S$. gallolyticus virulence factors through an ultrastructural study of surface components. In numerous other bacteria, cellular structures such as fimbriae and capsular material are associated with virulence.

\section{METHODS}

Bacterial strains and in vitro growth conditions. Fifteen pigeon $S$. gallolyticus strains representing high, moderate and low virulence supernatant-phenotypes were used in this study (Table 1). This selection of S. gallolyticus strains was representative for the serotypes and biotypes most frequently isolated from pigeons (Vanrobaeys et al., 1996). Bacterial strains from frozen stock $\left(-20^{\circ} \mathrm{C}\right)$ were thawed and grown overnight on Columbia agar (Gibco) with $5 \%$ bovine blood at
$37{ }^{\circ} \mathrm{C}$ in a $5 \% \quad \mathrm{CO}_{2}$-enriched environment and checked for purity. Volumes $(5 \mathrm{ml}$ ) of Todd-Hewitt broth (Oxoid) were then inoculated with one $S$. gallolyticus colony and incubated at $37^{\circ} \mathrm{C}$ in a $5 \% \mathrm{CO}_{2}$ atmosphere for $16-18 \mathrm{~h}$ without shaking.

To investigate if growth conditions had an impact on the expression of surface components, two $S$. gallolyticus strains, STR 357 and STR 598, were also grown on Todd-Hewitt agar (Oxoid) and on Columbia agar (Gibco) with $5 \%$ bovine blood and incubated at $37^{\circ} \mathrm{C}$ in a $5 \% \mathrm{CO}_{2}$ atmosphere for $16-18 \mathrm{~h}$. The capsular material of these agar-grown cells was only investigated after polycationic ferritin labelling as described below.

\section{Transmission electron microscopy}

(i) Capsule detection after immunostabilization. Broth-grown bacteria were harvested and washed once with $0.01 \mathrm{M}$ PBS $\left(0.137 \mathrm{M} \mathrm{NaCl}, 0.007 \mathrm{M} \quad \mathrm{K}_{2} \mathrm{HPO}_{4}, 0.0025 \mathrm{M} \mathrm{KH}_{2} \mathrm{PO}_{4}\right.$, $\mathrm{pH} 7 \cdot 3$ ). In order to avoid collapse of the capsules during the electron microscopy dehydration procedure, the bacterial suspensions were exposed to undiluted antisera for $1 \mathrm{~h}$ at $4{ }^{\circ} \mathrm{C}$. The antisera were raised in specific-pathogen-free pigeons against whole bacterial cells. For $12 \mathrm{~S}$. gallolyticus strains, postinoculation pigeon antisera were available from earlier experiments (De Herdt et al., 1994d; Vanrobaeys et al., 1996). For the other three strains (STR 723, STR 673 and PDH 774), postinoculation pigeon antisera from strains with an identical biotype, serotype and supernatant-phenotype identification (STR 598, STR 357 and PDH 762) were used. The antiserum titres tested in an ELISA as described by De Herdt et al. (1993) varied between 400 and $>6400$ (Table 1 ). Bacterial cells were then suspended in cacodylate buffer $(0 \cdot 1 \mathrm{M}, \mathrm{pH} 7 \cdot 0)$ containing $5 \%$ glutaraldehyde and $0.15 \%(\mathrm{w} / \mathrm{v})$ ruthenium red. Fixation was done for $2 \mathrm{~h}$ at $20^{\circ} \mathrm{C}$. Controls with preimmune serum or without antibody stabilization were processed simultaneously.

Thereafter the bacterial cells were immobilized in $3 \%$ agar, washed five times in cacodylate buffer with $0.05 \%$ ruthenium

Table 1. Capsule thickness and presence $(+)$ or absence $(-)$ of fimbriae in broth-grown S. gallolyticus strains after immunostabilization with homologous pigeon antisera (IS) or labelling with polycationic (PC) ferritin

\begin{tabular}{|c|c|c|c|c|c|c|c|}
\hline \multirow[t]{2}{*}{ Strain } & \multirow{2}{*}{$\begin{array}{l}\text { Supernatant } \\
\text {-phenotype }\end{array}$} & \multirow[t]{2}{*}{$V^{*}$} & \multirow{2}{*}{$\begin{array}{l}\text { Serotype } \\
\text { /biotype }\end{array}$} & \multirow{2}{*}{$\begin{array}{l}\text { Antiserum } \\
\text { titre }\end{array}$} & \multicolumn{2}{|c|}{ Capsule thickness (nm) } & \multirow[t]{2}{*}{ Fimbriae } \\
\hline & & & & & IS & PC ferritin & \\
\hline PDH 774 & $\mathrm{~A}^{-\mathrm{T} 1}$ & $\mathrm{H}$ & $1 / 1$ & $>6400$ & $40-50$ & $60-70$ & + \\
\hline PDH 762 & $\mathrm{~A}^{-} \mathrm{T} 1$ & $\mathrm{H}$ & $1 / 1$ & $>6400$ & $20-25$ & $65-75$ & + \\
\hline PDH 820 & $\mathrm{~A}^{-} \mathrm{T} 1$ & $\mathrm{H}$ & $3 / 1$ & 3200 & $35-45$ & $60-70$ & + \\
\hline PDH 827 & $\mathrm{~A}^{-} \mathrm{T} 2$ & $\mathrm{~L}$ & $1 / 2 b$ & 1200 & \multicolumn{2}{|c|}{ Irregular } & - \\
\hline STR 598 & $\mathrm{~A}^{-} \mathrm{T} 2$ & $\mathbf{L}$ & $3 / 2 b$ & $>6400$ & \multicolumn{2}{|c|}{ Irregular } & - \\
\hline STR 723 & $\mathrm{~A}^{-} \mathrm{T} 2$ & $\mathbf{L}$ & $3 / 2 b$ & $>6400$ & \multicolumn{2}{|c|}{ Irregular } & - \\
\hline MV 3 & $\mathrm{~A}^{-} \mathrm{T} 3$ & $M$ & $2 / 2 b$ & 1200 & $25-35$ & $55-65$ & + \\
\hline PDH 818 & $\mathrm{~A}^{-} \mathrm{T} 3$ & $M$ & $3 / 2 b$ & 1200 & $20-30$ & $55-65$ & - \\
\hline PDH 800 & $\mathrm{~A}^{-} \mathrm{T} 3$ & $M$ & $3 / 2 b$ & 1200 & $20-30$ & $60-70$ & - \\
\hline STR 357 & $\mathrm{~A}^{+} \mathrm{T} 1$ & $\mathrm{H}$ & $1 / 1$ & 400 & $70-80$ & $80-90$ & + \\
\hline STR 329 & $\mathrm{~A}^{+} \mathrm{T} 1$ & $\mathrm{H}$ & $2 / 1$ & $>6400$ & $55-65$ & $45-55$ & + \\
\hline STR 673 & $\mathrm{~A}^{+} \mathrm{T} 1$ & $\mathrm{H}$ & $1 / 1$ & 400 & $55-65$ & $65-75$ & + \\
\hline STR 669 & $\mathrm{~A}^{+} \mathrm{T} 1$ & $\mathrm{H}$ & $5 / 1$ & 3200 & $55-65$ & $65-75$ & + \\
\hline PDH 783 & $A^{+} T 2$ & $\mathrm{H}$ & $1 / 1$ & 400 & $20-30$ & $60-70$ & + \\
\hline PDH 668 & $\mathrm{~A}^{+} \mathrm{T} 3$ & $\mathrm{H}$ & $2 / 1$ & 600 & $25-30$ & $40-50$ & + \\
\hline
\end{tabular}

*Virulence for pigeons after experimental infection: $\mathrm{H}$, high; $\mathrm{M}$, moderate; $\mathrm{L}$, low. 

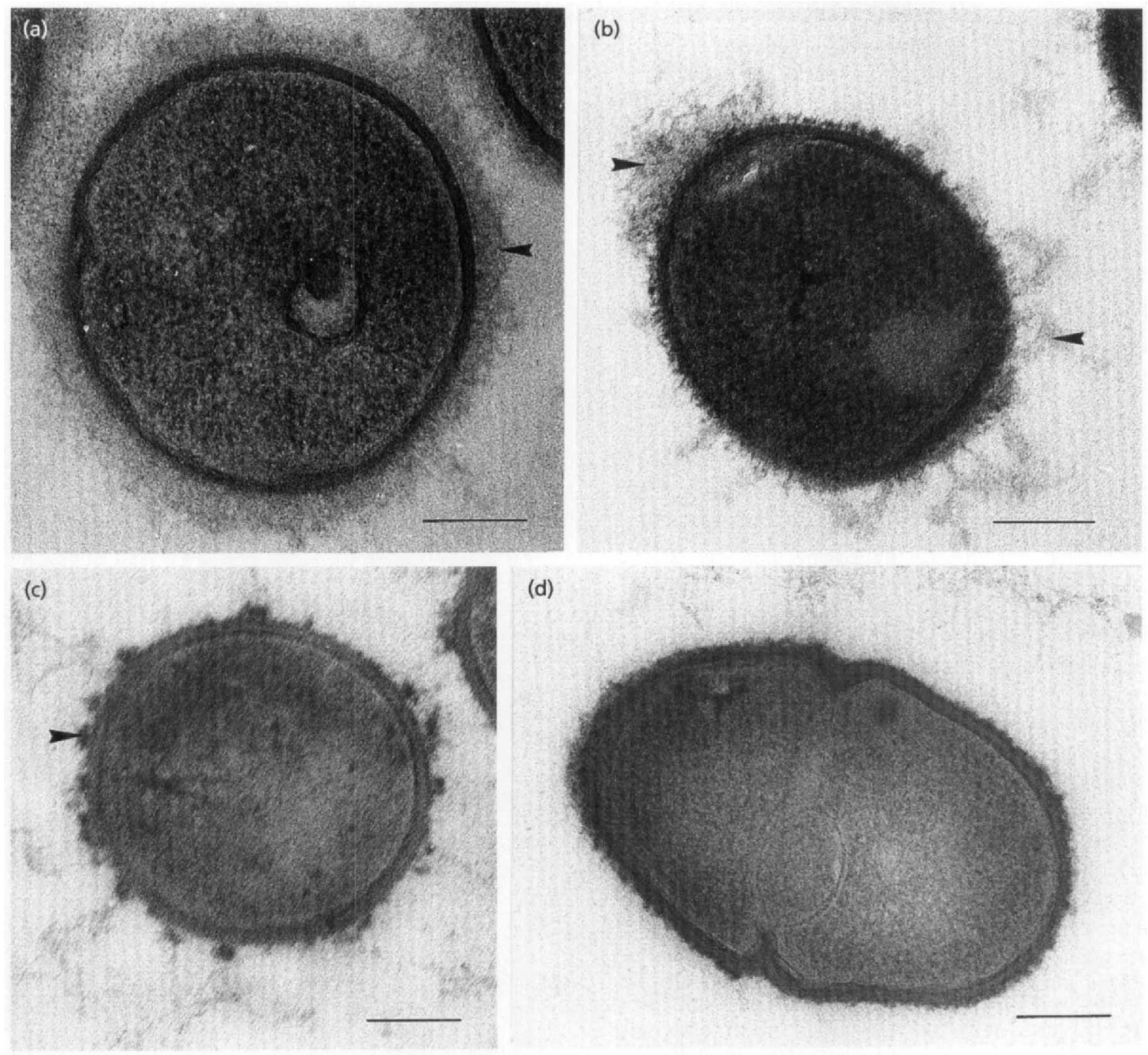

(d)

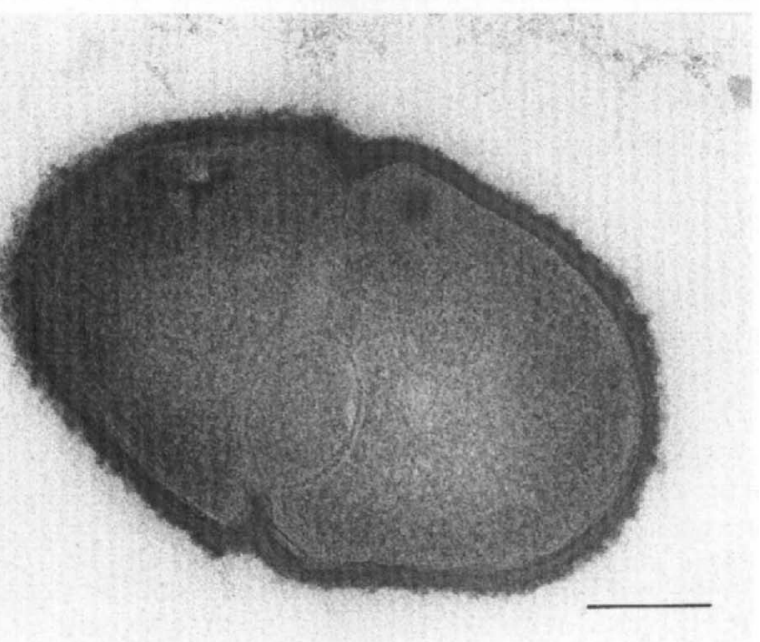

Fig. 1. Transmission electron micrographs of thin sections of $S$. gallolyticus cells grown on Todd-Hewitt broth. (a, b) Cells of strain STR 357 (a) and STR 598 (b) stabilized with whole-cell homologous antiserum. (c, d) Cells of strain STR 357 stained with ruthenium red only (c) and treated with preimmune serum (d). Arrows show capsular material. Bar, $150 \mathrm{~nm}$.

red and postfixed with $1 \%$ osmium tetroxide and $0.05 \%$ ruthenium red for $2 \mathrm{~h}$. Washings were repeated as above, and the samples were dehydrated in a graded series of acetone washes. All the solutions used in processing the specimen, from the wash after glutaraldehyde fixation to dehydration with the $70 \%$ acetone solution, contained $0.05 \%$ ruthenium red. Samples were then washed twice in propylene oxide and embedded in Spurr low-viscosity resin. Thin sections were cut and stained with uranyl acetate and lead citrate. They were examined with a transmission electron microscope (Philips $208 \mathrm{~S}$ ) at an accelerating voltage of $60 \mathrm{kV}$.

(ii) Capsule detection after polycationic ferritin labelling. Bacteria were harvested and washed once with PBS. Thereafter, bacterial cells were fixed for $2 \mathrm{~h}$ at $20^{\circ} \mathrm{C}$ in cacodylate buffer containing $5 \%$ glutaraldehyde and $0.15 \%$ ruthenium red. Fixed bacteria were suspended in cacodylate buffer and allowed to react with the polycationic ferritin (final concentration $1.0 \mathrm{mg} \mathrm{m}^{-1}$; Sigma) for $30 \mathrm{~min}$ at $20^{\circ} \mathrm{C}$ (Jacques $\&$ Foiry, 1987). The reaction was stopped by 10 -fold dilution with buffer, and the cells were centrifuged and washed three times in cacodylate buffer. Bacterial cells were then immobilized in $3 \%$ agar and processed as described above.

(iii) Detection of fimbriae after negative staining. S. gallolyticus cultures were washed once in PBS and then suspended in a minimal amount of distilled water. A Formvar-coated copper grid was floated on the surface of the bacterial suspension for $10 \mathrm{~min}$. The grid was then floated for $10 \mathrm{~s}$ on a solution of $1 \%$ $(\mathrm{w} / \mathrm{v})$ methylamine tungstate or $2 \%(\mathrm{w} / \mathrm{v})$ uranyl acetate in distilled water. After staining, the grid was washed twice and examined with a Philips $208 \mathrm{~S}$ transmission electron microscope.

(iv) Measurements. Capsule thickness and size of fimbriae were measured on micrographs taken during the electron microscopic observations. For each $S$. gallolyticus strain, mean values were calculated from 10-15 S. gallolyticus cells per micrograph; each experiment was done at least three times. The cell wall thickness was measured between the inner edge of the capsule layer and the outer leaflet of the plasma membrane. 


\section{RESULTS}

\section{Immunostabilization and polycationic ferritin labelling}

Electron microscopy of thin sections of bacterial cells showed small (approx. 0.6 $\mu \mathrm{m}$ ) spherical to ovoid cocci, occurring singly or in pairs. The cell wall thickness, measured between the inner edge of the capsule layer and the outer leaflet of the plasma membrane, was $22-26 \mathrm{~nm}$ for all strains.

After stabilization with antisera, cells of all strains were covered with a layer of capsular material. The thickness of this capsule varied between the different strains and had no apparant relation to the antiserum titre (Table 1). The thickest capsular layer $(55-80 \mathrm{~nm})$ was seen around cells from the highly virulent $S$. gallolyticus $\mathrm{A}^{+} \mathrm{T} 1$ strains. Highly virulent $\mathrm{A}^{-} \mathrm{T} 1, \mathrm{~A}^{+} \mathrm{T} 2$ and $\mathrm{A}^{+} \mathrm{T} 3$ strains, as well as moderately virulent $\mathrm{A}^{-} \mathrm{T} 3$ strains had a $20-50 \mathrm{~nm}$ thick capsule. The capsules of all highly (Fig. 1a) and moderately virulent strains had a regular, continuous appearance, whereas the capsule of the $S$. gallolyticus strains belonging to the low virulence $\mathrm{A}^{-} \mathrm{T} 2$ group was irregular (Fig. 1b). Some cells had almost no capsular material whilst other cells of the same strain had a capsule showing alternating areas with a narrow layer or with long appendages, up to $150 \mathrm{~nm}$ long (Fig. $1 \mathrm{~b})$. Electron microscopy of thin sections of bacterial cells without antisera and stained with ruthenium red only revealed the presence of a small amount of condensed capsular material surrounding the cells (Fig. 1c). The capsular material collapsed during the dehydration process. Capsular material on bacteria treated with preimmune serum was not stabilized (Fig. 1d).

Broth-grown bacterial cells labelled with polycationic ferritin were covered with a continuous layer of ferritin granules. Capsule thickness varied between the different strains (Table 1). The capsules of the $S$. gallolyticus strains belonging to the virulent $\mathrm{A}^{+} \mathrm{T} 1, \mathrm{~A}^{+} \mathrm{T} 2, \mathrm{~A}^{+} \mathrm{T} 3$, $A^{-} \mathrm{T} 1$ and $A^{-} \mathrm{T} 3$ supernatant-phenotypes were covered with a dense layer of ferritin granules (Fig. 2a). The labelled capsular material surrounded the cells completely and had a regular, continuous appearance. The capsule thickness of broth-grown virulent S. gallolyticus strains varied between 40 and $90 \mathrm{~nm}$. Cells of $S$. gallolyticus strains belonging to the low virulence $\mathrm{A}^{-} \mathrm{T} 2$ group, grown and treated under similar conditions, exhibited a complete but irregular layer of ferritin granules showing alternating areas with a narrow rim or with long appendages of capsular material. Due to this irregular outline, capsule thickness could not be measured. Cells of strains STR 598 and STR 723 (Fig. 2b) exibited a thinner capsule than cells of strain PDH 827. The capsule of the latter was also irregular but rather thick and the polycationic-ferritin-labelled capsular material was less dense (Fig. 2c) compared to the dense, homogeneous capsular layer of the virulent strains (Fig. $2 \mathrm{a})$. These results matched the findings of the immunostabilization. However, capsular material from cells labelled with polycationic ferritin was usually thicker than that from cells exposed to antiserum.
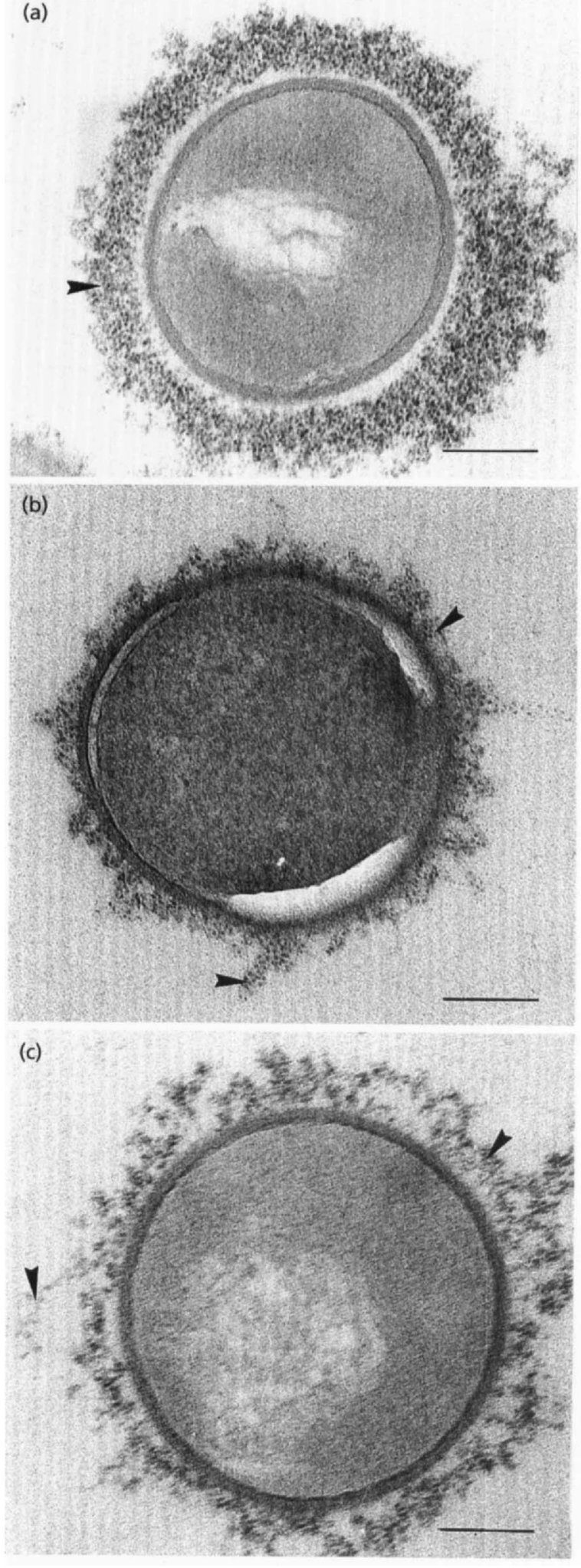

Fig. 2. Transmission electron micrographs of thin sections of $S$. gallolyticus cells labelled with polycationic ferritin. (a) Cells of the high virulence strain STR 357 grown on Columbia agar with $5 \%$ bovine blood. (b, c) Cells of the low virulence strains STR 723 (b) and PDH 827 (c) grown on Todd-Hewitt broth. Arrows show capsular material. Bar, $150 \mathrm{~nm}$. 

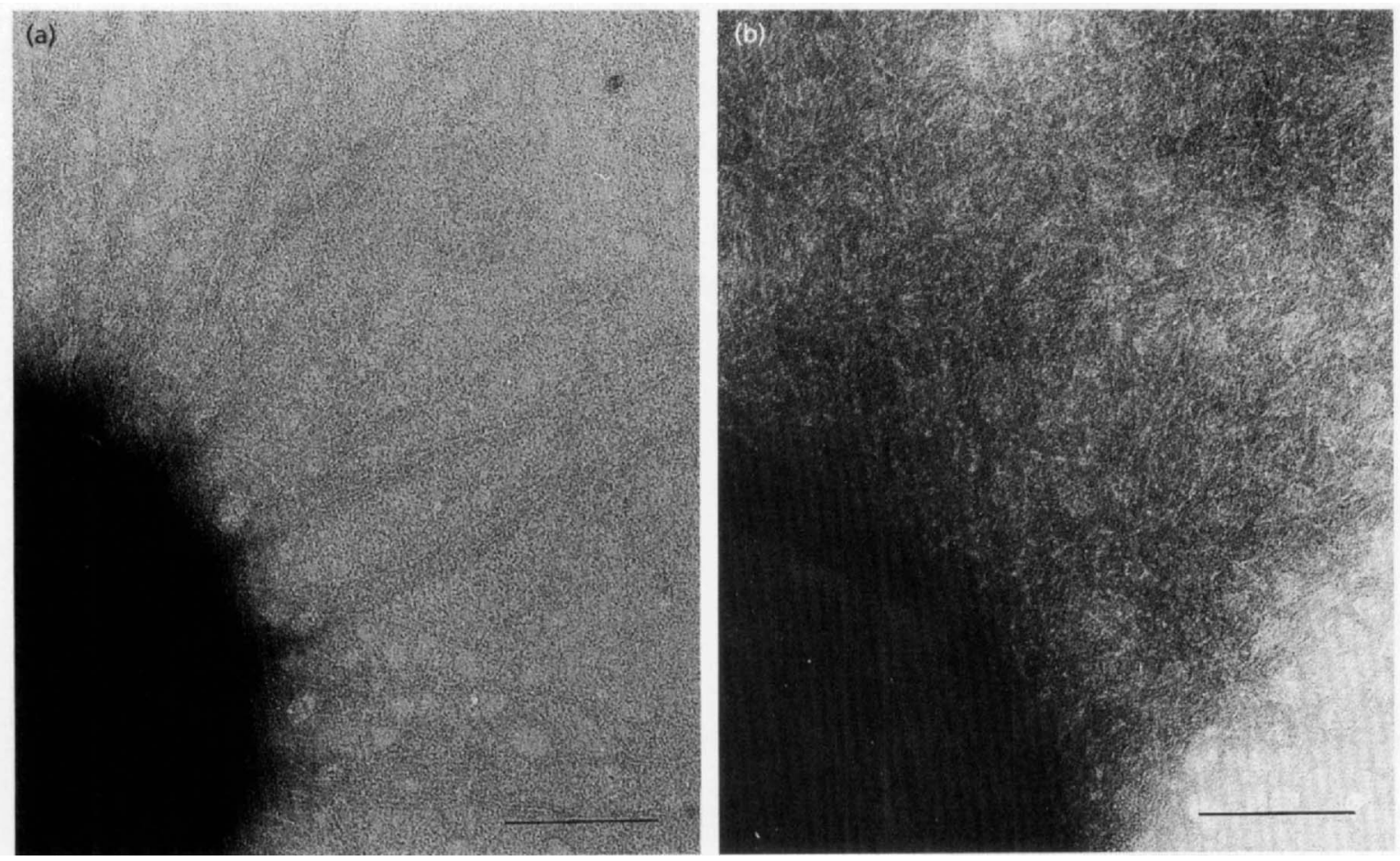

Fig. 3. Transmission electron micrographs of negatively stained preparations of S. gallolyticus grown in Todd-Hewitt broth. (a) Strain STR 357 with fimbriae extending from the cell surface. (b) Strain STR 598 with large dense masses of fibrous material associated with the cells. (Bar, $150 \mathrm{~nm}$ ).

Cells of the virulent strain STR 357 cultured on solid medium (Fig. 2a) expressed capsules extending further from the cell surface $(90-110 \mathrm{~nm})$ than cells cultured in broth medium $(80-90 \mathrm{~nm})$. The capsule had a similar ultrastructural appearance as the capsules of brothgrown cells described above. There was no difference in capsule thickness when cells were grown on ToddHewitt agar or on Columbia agar with $5 \%$ bovine blood. The capsule of the low virulence STR 598 cells, grown on Todd-Hewitt agar or on Columbia agar with $5 \%$ bovine blood, exhibited an irregular, thin capsule as described above. However, when grown on solid medium, the capsule did not surround the cells completely.

\section{Negative staining}

We investigated the surface of $S$. gallolyticus strains after negative staining. This procedure demonstrated the presence of a peritrichous array of surface fimbriae extending outward from the cell walls of all S. gallolyticus strains belonging to the $\mathrm{A}^{+} \mathrm{T} 1, \mathrm{~A}^{-} \mathrm{T} 1, \mathrm{~A}^{+} \mathrm{T} 2$ and $\mathrm{A}^{+} \mathrm{T} 3$ culture-supernatant groups and in one strain of the $\mathrm{A}^{-} \mathrm{T} 3$ group (Table 1 ). There were no differences noticed between methylamine tungstate or uranyl acetate as negative stains. The fimbriae were flexible structures with a length of $500-700 \mathrm{~nm}$ and a width of 3-4 nm (Fig. 3a). These dimensions were very similar in all strains studied. The fimbriae showed no definite substructure. The density of the fimbriae varied considerably from cell to cell, from dense to sparse, in cells of a single strain. Not all cells in a culture were fimbriated.

Fimbriae as described above could not be detected in the three $S$. gallolyticus strains belonging to the low virulence $\mathrm{A}^{-} \mathrm{T} 2$ culture-supernatant group. In these strains, a small number of cells produced large dense masses of very tightly packed fibrous material (Fig. 3b), structurally distinct from the fimbriae shown in Fig. 3(a) but also produced from the cell surface.

When grown on solid media, no fimbriae could be detected on cells belonging to the low virulence strain STR 598. The fibrous material produced from the cell surface of broth-grown cells was not produced when grown on agar media. Long thin fimbriae as described above were present on cells of the virulent strain STR 357. However, there was a difference in the number of cells expressing fimbriae on the two solid media tested. When grown on Columbia agar with $5 \%$ bovine blood, only a few cells expressed fimbriae. When grown on Todd-Hewitt agar, the number of cells that expressed fimbriae was greater and similar to that when cells were grown in broth medium.

\section{DISCUSSION}

There was a remarkable association between ultrastructure and virulence for pigeons of the S. gallolyticus strains examined. Strains belonging to the high and moderate virulence supernatant-phenotypes of $S$. gallolyticus were covered with a uniform and continuous 
layer of capsular material with a dense granulation of polycationic ferritin. In the non-virulent $\mathrm{A}^{-} \mathrm{T} 2$ strains, the capsule was irregular and less densely labelled with polycationic ferritin. The differences in capsule morphologies were similar after immunostabilization or polycationic-ferritin-labelling. Moreover, non-virulent $\mathrm{A}^{-} \mathrm{T} 2$ strains lacked fimbriae. In the moderately virulent $\mathrm{A}^{-} \mathrm{T} 3$ group, fimbriae were only present in one of the three strains examined. Strains belonging to the highly virulent supernatant-phenotypes, however, all carried fimbriae. This may indicate that the capsule and/or fimbriae are involved in virulence of $S$. gallolyticus for pigeons.

In many streptococci, the capsule is considered an important virulence factor (De Velasco et al., 1995; Timoney, 1993). The role of the capsule in virulence of the bacterium is however mainly determined by its chemical composition. Of critical importance is the presence of sialic acid (Timoney, 1993; Wessels et al., 1989), hyaluronic acid (Dale et al., 1996; Leigh et al., 1990; Moses et al., 1997; Whitnack et al., 1981) or the M protein (Fischetti, 1989; Moses et al., 1997) since these components interact with the host defence mechanisms in several ways, promoting the invasive character of the bacteria. In view of the morphological differences in capsular material between virulent and low virulence pigeon $S$. gallolyticus strains, it would be interesting to study the chemical composition of the capsule in pigeon $S$. gallolyticus strains in more detail.

Conventional fixation for thin-section electron microscopy is insufficient to preserve bacterial capsular material, a highly hydrated structure which collapses during dehydration and embedding. Ruthenium red is a polycationic dye with specificity for polycationic polymers such as acidic polysaccharides. Although it has been widely used to stain bacterial capsular polysaccharides, ruthenium red does not protect capsular material against collapse and condensation, except when attachment to surfaces anchors the fibres and maintains their extended configuration, or when the capsule is stabilized by specific antibodies or lectins (Costerton $e t$ al., 1981; Jacques \& Foiry, 1987; Molinari et al., 1988). Cross-linking activity of polycationic ferritin, a large electron-dense molecule, can also protect capsular material from collapse. The binding of polycationic ferritin is entirely electrostatic and can be considered specific for sulfate and carboxyl groups of acidic glycoconjugates and glycosaminoglycans (Erdos, 1986).

The capsular material of $S$. gallolyticus was stabilized during processing for electron microscopy using antibodies or polycationic ferritin. Both techniques gave similar results in our study. Nevertheless, the capsular material was best observed when labelled with polycationic ferritin, suggesting that it might be rich in acidic polysaccharides (Erdos, 1986). After stabilization with antibodies, the capsular material was thinner, indicating that the capsules were only partially stabilized. The partial stabilization may be due to an antibody concentration insufficient for complete stabilization. This phenomenon has also been observed with Pasteurella multocida (Jacques \& Foiry, 1987) and Staphylococcus aureus (Caputy \& Costerton, 1982). It is possible that the antibody concentration in antisera may be high when tested against whole cells, yet stabilization of the glycocalyx may not be found (Caputy $\&$ Costerton, 1982). In our study the antisera titres raised against whole cells varied between 400 and $>6400$, but there was apparently no correlation between serum titre and capsule stabilization.

A capsule was detected in all pigeon S. gallolyticus strains examined. The presence of a capsule has also been described in S. bovis, presumably S. gallolyticus, isolates from cattle, sheep (Garvie \& Bramley, 1979; Medrek \& Barnes, 1962) and humans (Molinari et al., 1988), as well as in numerous other streptococci such as Streptococcus pyogenes (Moses et al., 1997), Streptococcus suis (Charland et al., 1996; Jacques et al., 1990), Streptococcus uberis (Leigh et al., 1990), Streptococcus pneumoniae (De Velasco et al., 1995) and Streptococcus agalactiae (Kubin \& Ryc, 1988; Von Hunolstein et al., 1993). The present study thus confirms that the presence of a capsule is a common feature in streptococci.

In the present study, surface appendages were seen on cells of some of the pigeon $S$. gallolyticus strains examined. These structures fitted the general description of fimbriae proposed by Ottow (1975). Fimbriae are most common in Gram-negative bacteria, but have also been described in a few streptococcal species such as Streptococcus salivarius (Handley et al., 1984; Handley et al., 1988), Enterococcus faecalis (Handley \& Jacob, 1981), Streptococcus sanguis (now S. sanguinis) (Handley et al., 1985; Willcox et al., 1989) and S. suis (Jacques et al., 1990). Semjén \& Galfi (1990) performed an ultrastructural study of ruminant $S$. bovis, presumably $S$. gallolyticus, strains but failed to detect fimbriae. As far as we know, the present paper provides the first description of fimbriae in S. gallolyticus.

In $S$. gallolyticus strains representing the low virulence $\mathrm{A}^{-} \mathrm{T} 2$ culture-supernatant group, no fimbriae as described in the virulent pigeon $S$. gallolyticus strains could be detected. Instead, an extracellular layer of large dense masses of tightly packed fibrous material was produced from a small number of cells. This layer resembles the fibrous material on some cells of strains $\mathrm{JH} 2$ and $\mathrm{JH} 3$ of E. faecalis described by Handley \& Jacob (1981). This extracellular material was never detected on virulent pigeon $S$. gallolyticus strains and was not produced when cells were grown on solid media. We do not know if this extracellular layer was of capsule or fimbrial nature. Studies on the chemical composition of the extracellular structures of $S$. gallolyticus might give additional information.

The present study of bacterial cell surface ultrastructure was performed using cells grown in Todd-Hewitt broth. Under these conditions a correlation was found between 
the presence of fimbriae and a continuous appearance of the capsule on the one hand, and virulence in vivo and supernatant-phenotype on the other hand. Limited tests comparing other growth conditions suggest that these do influence capsule thickness and fimbrial expression to some extent.

For many bacterial pathogens, capsule production is suppressed or lost after repeated subcultivation (Costerton et al., 1981; Wibawan \& Lämmler, 1994). In this study, $S$. gallolyticus strains were not serially passaged. Capsules were observed when cells were stabilized with either homologous antisera or with cationized ferritin. Discontinuous capsules were observed on the low virulence strains regardless of the stabilization method employed. All these findings suggest that our observations are not likely to be artifactual, but an accurate reflection of the cell wall surface character of pigeon $S$. gallolyticus strains.

In the Enterobacteriaceae, fimbriae serve as ligands during attachment to epithelial cells (Müller et al., 1991; Ofek \& Doyle, 1994). For the streptococci, the relationship between the presence of ultrastructural appendages and adhesion has been firmly established only in S. salivarius (Handley et al., 1987; Weerkamp et al., 1986). In pigeon $S$. gallolyticus and all other streptococci, the role of fimbriae is not known. In preliminary studies using pigeon, chicken, pig and sheep erythrocytes, pigeon $S$. gallolyticus strains were unable to cause haemagglutination.

In all pigeon $S$. gallolyticus strains examined, the cell wall thickness was $22-26 \mathrm{~nm}$. This cell wall thickness appeared characteristic of pigeon $S$. gallolyticus strains since similar values were observed for the strains studied that represented different serotypes and culture-supernatant-phenotypes. Furthermore, this is comparable to other Gram-positive bacteria, in which cell wall thickness varies between 20 and $50 \mathrm{~nm}$ (Shockman \& Barrett, 1983).

S. gallolyticus ( $S$. bovis) has been isolated from numerous animal species and from humans (De Herdt, 1993; Garvie \& Bramley, 1979; Medrek \& Barnes, 1962). Except for some limited studies in human (Molinari et al., 1988) and ruminant (Semjén \& Galfi, 1990) strains, ultrastructural studies of this bacterial species have not been performed on isolates from any of these hosts. The present paper describes the ultrastructure of 15 pigeon $S$. gallolyticus strains. It is not known whether isolates from other animals or humans have similar morphological characteristics.

In conclusion, the results of this ultrastructural study indicate that virulent and some moderately virulent pigeon S. gallolyticus cells bear fimbriae and that the capsules from virulent and low virulence $S$. gallolyticus strains have distinct morphologies. Because of their possible role in virulence it is important that the surface properties and the function of surface appendages are studied in more detail.

\section{ACKNOWLEDGEMENTS}

This work was supported by a grant from the Flemish Institute for the Advancement of Scientific-technological Research in Industry (IWT, Brussels, Belgium) to Mia Vanrobaeys. The authors want to thank Intervet Belgium and the Research Grant of the Fund for Scientific Research (FWO, Flanders, Belgium) for their financial support. N. Dubois, M. Ledecq, L. Hauttekeete and A. Vandekerckhove are acknowledged for their skilled technical assistance.

\section{REFERENCES}

Caputy, G. G. \& Costerton, J. W. (1982). Morphological examination of the glycocalyces of Staphylococcus aureus strains Wiley and Smith. Infect Immun 36, 759-767.

Charland, N., Kobisch, M., Martineau-Doizé, B., Jacques, M. \& Gottschalk, M. (1996). Role of capsular sialic acid in virulence and resistance to phagocytosis of Streptococcus suis capsular type 2. FEMS Immunol Med Microbiol 14, 195-203.

Costerton, J. W., Irvin, R. T. \& Cheng, K.-J. (1981). The bacterial glycocalyx in nature and disease. Annu Rev Microbiol 35, 299-324.

Dale, J. B., Washburn, R. G., Marques, M. B. \& Wessels, M. R. (1996). Hyaluronate capsule and surface $M$ protein in resistance to opsonization of group A streptococci. Infect Immun 64, 1495-1501.

De Herdt, P. (1993). Streptococcosis in pigeons: the bacterium and its interaction with the host. PhD thesis, University of Ghent, Belgium.

De Herdt, P., Devriese, L. A., Uyttebroeck, E., Ducatelle, R. \& Haesebrouck, F. (1991). Streptococcus bovis infecties bij duiven. Vlaams Diergeneeskd Tijdschr 60, 51-54.

De Herdt, P., Haesebrouck, F., Devriese, L. A. \& Ducatelle, R. (1992a). Biochemical and antigenic properties of Streptococcus bovis isolated from pigeons. J Clin Microbiol 30, 2432-2434.

De Herdt, P., Desmidt, M., Haesebrouck, F., Ducatelle, R. \& Devriese, L. A. (1992b). Experimental Streptococcus bovis infections in pigeons. Avian Dis 36, 916-925.

De Herdt, P., Haesebrouck, F., Devriese, L. A. \& Ducatelle, R. (1993). Prevalence of antibodies to Streptococcus bovis serotype 1 in racing pigeons. $J$ Vet Med Ser B 40, 494-500.

De Herdt, P., Ducatelle, R., Haesebrouck, F., Devriese, L. A., De Groote, B. \& Roels, S. (1994a). An unusual outbreak of Streptococcus bovis septicaemia in pigeons (Columba livia). Vet Rec 134, $42-43$.

De Herdt, P., Haesebrouck, F., Devriese, L. A. \& Ducatelle, R. (1994b). Prevalence of Streptococcus bovis in racing pigeons. Vet Q 16, 71-74.

De Herdt, P., Haesebrouck, F., Ducatelle, R., De Groote, B. \& Devriese, L. A. (1994c). Streptococcus bovis infections in pigeons: virulence of different serotypes. Vet Microbiol 41, 321-332.

De Herdt, P., Haesebrouck, F., Devriese, L. A. \& Ducatelle, R. (1994d). Immunity in pigeons against homologous and heterologous serotypes of Streptococcus bovis after infection. Vet Microbiol 42, 111-119.

De Velasco, E. A., Verheul, A. F. M., Verhoef, J. \& Snippe, H. (1995). Streptococcus pneumoniae: virulence factors, pathogenesis, and vaccines. Microbiol Rev 59, 591-603.

Devriese, L. A., Uyttebroeck, E., Gevaert, D., Vandekerckhove, P. \& Ceyssens, K. (1990). Streptoccocus bovis infections in pigeons. Avian Pathol 19, 429-434. 
Devriese, L. A., Vandamme, P., Pot, B., Vanrobaeys, M., Kersters, K. \& Haesebrouck, F. (1998). Differentiation between Streptococcus gallolyticus strains of human clinical and veterinary origins and Streptococcus bovis strains from the intestinal tracts of ruminants. J Clin Microbiol 36, 3520-3523.

Erdos, G.W. (1986). Localization of carbohydrate-containing molecules. In Ultrastructure Techniques for Microorganisms, pp. 399-420. Edited by H. C. Aldrich \& W. J. Todd. New York: Plenum.

Fischetti, V. A. (1989). Streptococcal M protein: molecular design and biological behavior. Clin Microbiol Rev 2, 285-314.

Garvie, E. I. \& Bramley, A. J. (1979). Streptococcus bovis - an approach to its classification and its importance as a cause of bovine mastitis. J Appl Bacteriol 46, 557-566.

Handley, P. S. \& Jacob, A. E. (1981). Some structural and physiological properties of fimbriae of Streptococcus faecalis. J Gen Microbiol 127, 289-293.

Handley, P. S., Carter, P. L. \& Fielding, J. (1984). Streptococcus salivarius strains carry either fibrils or fimbriae on the cell surface. J Bacteriol 157, 64-72.

Handley, P. S., Carter, P. L., Wyatt, J. E. \& Hesketh, L. M. (1985). Surface structures (peritrichous fibrils and tufts of fibrils) found on Streptococcus sanguis strains may be related to their ability to coaggregate with other oral genera. Infect Immun 47, 217-227.

Handley, P. S., Harty, D. W. S., Wyatt, J. E., Brown, C. R., Doran, J.P. \& Gibbs, A. C. C. (1987). A comparison of the adhesion, coaggregation and cell-surface hydrophobicity properties of fibrillar and fimbriate strains of Streptococcus salivarius. J Gen Microbiol 133, 3207-3217.

Handley, P. S., Hargreaves, J. \& Harty, D. W. S. (1988). Ruthenium red staining reveals surface fibrils and a layer external to the cell wall in Streptococcus salivarius $\mathrm{HB}$ and adhesion deficient mutants. J Gen Microbiol 134, 3165-3172.

Jacques, M. \& Foiry, B. (1987). Electron microscopic visualization of capsular material of Pasteurella multocida types A and D labeled with polycationic ferritin. J Bacteriol 169, 3470-3472.

Jacques, M., Gottschalk, M., Foiry, B. \& Higgins, R. (1990). Ultrastructural study of surface components of Streptococcus suis. J Bacteriol 172, 2833-2838.

Kubin, V. \& Ryc, M. (1988). Adherence of group B streptococci to human buccal epithelial cells. Its dependence on the biological state of the culture. Folia Microbiol 33, 224-229.

Leigh, J. A., Field, T. R. \& Williams, M. R. (1990). Two strains of Streptococcus uberis, of differing ability to cause clinical mastitis, differ in their ability to resist some host defence factors. Res Vet Sci 49, 85-87.

Medrek, T. F. \& Barnes, E. M. (1962). The physiological and serological properties of Streptococcus bovis and related organisms isolated from cattle and sheep. J Appl Bacteriol 25, 169-179.

Molinari, A., Orefici, G., Donelli, G., Von Hunolstein, C., Paradisi, S. \& Arancia, G. (1988). Preservation of capsular material of streptococcal cells by specific lectins determined by immunoelectron microscopy. Histochem J 20, 526-530.

Moses, A. E., Wessels, M. R., Zalcman, K., Alberti, S., NatansonYaron, S., Menes, Y. \& Hanski, E. (1997). Relative contribution of hyaluronic acid capsule and $M$ protein to virulence in a mucoid strain of the group A streptococcus. Infect Immun 65, 64-71.

Müller, K. H., Collinson, S. K., Trust, R. J. \& Kay, W. W. (1991). Type 1 fimbriae of Salmonella enteritidis. J Bacteriol 173, $4765-4772$.

Ofek, I. \& Doyle, R. J. (editors) (1994). Bacterial Adhesion to Cells and Tissues, pp. 1-40. New York: Chapman \& Hall.

Ottow, J. C. G. (1975). Ecology, physiology, and genetics of fimbriae and pili. Annu Rev Microbiol 29, 79-108.

Semjén, G. \& Galfi, P. (1990). Factors influencing the adherence of strains of Streptococcus bovis and Escherichia coli isolated from ruminal epithelium. Vet Res Commun 14, 181-191.

Shockman, G. D. \& Barrett, J. F. (1983). Structure, function, and assembly of cell walls of Gram-positive bacteria. Annu Rev Microbiol 37, 501-527.

Timoney, J. F. (1993). Streptococcus. In Pathogenesis of Bacterial Infections in Animals, pp. 3-20. Edited by C. L. Gyles \& C. O. Thoen. Ames: Iowa State University Press.

Vanrobaeys, M., De Herdt, P., Haesebrouck, F., Ducatelle, R. \& Devriese, L. A. (1996). Secreted antigens as virulence associated markers in Streptococcus bovis strains from pigeons. Vet Microbiol 53, 339-348.

Vanrobaeys, M., De Herdt, P., Ducatelle, R., Creten, W. \& Haesebrouck, F. (1997). Extracellular proteins and virulence in Streptococcus bovis isolates from pigeons. Vet Microbiol 54, 59-66.

Von Hunolstein, C., D'Ascenzi, S., Wagner, B., Jelinkova, J., Alfarone, G., Recchia, S., Wagner, M. \& Orefici, G. (1993). Immunochemistry of capsular type polysaccharide and virulence properties of type VI Streptococcus agalactiae (group B streptococci). Infect Immun 61, 1272-1280.

Weerkamp, A. H., Handley, P. S., Baars, A. \& Slot, J. W. (1986). Negative staining and immunoelectron microscopy of adhesiondeficient mutants of Streptococcus salivarius reveal that the adhesive protein antigens are separate classes of cell surface fibril. $J$ Bacteriol 165, 746-755.

Wessels, M. R., Rubens, C. E., Benedi, V. J. \& Klasper, D. L. (1989). Definition of a bacterial virulence factor: sialylation of the group B streptococcal capsule. Proc Natl Acad Sci USA 86, 8983-8987.

Whitnack, F., Bisno, A. L. \& Beachey, E. H. (1981). Hyaluronate capsule prevents attachment of group A streptococci to mouse peritoneal macrophages. Infect Immun 31, 985-991.

Wibawan, I. W. T. \& Lämmler, C. (1994). Relation between encapsulation and various properties of Streptococcus suis. I Vet Med Ser B 41, 453-459.

Willcox, M. D. P., Wyatt, J. E. \& Handley, P. S. (1989). A comparison of the adhesive properties and surface ultrastructure of the fibrillar Streptococcus sanguis 12 and an adhesion deficient non-fibrillar mutant 12 na. J Appl Bacteriol 66, 291-299.

Received 22 June 1998; revised 1 September 1998; accepted 16 October 1998. 